\title{
Pencarian Data Barang Produk Atribut Sekolah Menggunakan Algoritma Binary Search
}

\author{
Risma Dara Awal Aviantika1);Kustanto2); Muhammad Hasbi3) \\ 1,3) Program Studi Informatika, STMIK Sinar Nusantara \\ 2)ProgramStudi Teknologi Informasi, STMIK Sinar Nusantara \\ 1)riezmhadarae@gmail.com;2)kustanto@sinus.ac.id;3)mhasbi@sinus.ac.id
}

\begin{abstract}
Technology and information grows rapidly should be supported with appropriate needs. Therefore, the writers create data searching for school attribute using Binary Algorithm application. There are many methods which having purpose to make easier in search data of school attribute with binary search algorithm method. Data searching of convection is used manually. The purpose of this research isto create a data retrieval system which is implemented as data retrieval. It changes the manually system to computerized system. This research used Binary Search Algorithm. Binary search algorithm is a technique applied only for sequenced element. This research used Binary Search Algorithm method. The design ofBinary Search Algorithm method are data analyzing, system planning, coding, testing and implementing. The data collecting used observation and bibliography. Then, system planning usedUnified Modelling Language (UML). The system design used the Java programming language with Netbeans and MySQL Server. Meanwhile, implementing system used to collectingdata retrieval of goods. To know the eligibility of a system, it needs the searching times for 210 data every 0.0004 seconds, 0.0005 seconds, 0.0006 seconds, 0.0007 seconds, 0.0008 seconds, 0.0009 seconds, 0.0010 seconds, 0.0012 seconds, 0.0014 seconds, and 0.00117 seconds. The result of this research is implemented Binary Searching Algorithm Method.

Keywords : Data, Product, Binary Searching,Binary Search Algorithm.
\end{abstract}

\section{PENDAHULUAN}

Perkembangan teknologi informasi saat ini semakin maju termasuk dalam pencarian file, pencarian fileini akan dapat kita selesaikan dengan menggunakan beberapa metode pencarian.Contonya metode pencarian seperti pencarian beruntun (sequential Searching), pencarian Biner dan pencarian berindeks. Setiap metode mempunyai kelebihan dan kekurangan. Metode pencarian beruntun merupakan metode yang paling umum dan paling kita jumpai dalam kehidupan sehari-hari yaitu pencarian yang dilakukan dengan membandingkan satu-persatu data hinggga data tersebut ditemukan, waktu pencarian sangat lama, cocok untuk jumlah data yang sediit atau dengan kata lain metodenya adalah file atau folder diurutkan secara Ascending [A........Z] yaitu mengurutkan file yang lebih kecil ke file yang lebih besar dengan melakukan perbandingan antara file pertama dengan file kedua jika ditemukan maka pencarian akan dihentikan tetapi jika belum ditentukan maka akan dilanjutkan ke file berikutnya sampai file tersebut ditemukan[1].

Dari uraian di atas, penerapan metode pencarian biner (Binary Search) pada pencarian data barang produksi bertujuan untuk mengatasi kendala pencarian data barang.

Permasalah yang terjadi dalam pencarian data barang diantaranya adalah :

a. Konveksi dalam pencarian data barang produksi topi, dasi, ikat pinggang kaos kaki, bed masih menggunakan cara manual dengan mencari data arsip yang tertulis di dalam buku catatan sedangkan jenis barang produksi sebanyak 5 item tanpa menerapkan suatu pencarian yang lebih teliti terhadap pencarian data barang, sehingga berakibat data yang dicari terkadang ada kesalahan menentukan jumlah barang sehingga jika dicari dengan cara tersebut akan memakan waktu dan menyebabkan pelayanan terhadap pelanggan terlambat.

b. Belum ada aplikasi pencarian data barang yang berbasis komputerisasi, yang mampu mencari data barang yang teliti.

Penyelesaian masalah diatas dapat menggunakan algoritma binary search untuk mencari data barang produksi.

\section{TINJAUAN PUSTAKA}

1. Pencarian

Pengolahan data secara terstruktur yang dilakukan melalui proses fundamental. Proses 
ini biasa diterapkan dalam mengupdate data di sebuah sistem larik [2].

Pencarian (Searching) dapat diartikan sebagai pekerjaan sehari-hari untuk mengetahui apakah data yang diinginkan ada dalam sekumpulan data, sehingga jika diperlukan dapat diketaui posisi data tersebut [3].

Menurut kamus besar bahasa indonesia pencarian merupakan proses, cara atau perbuatan mencari. Dalam ilmu komputerisasi pencarian adalah kegiatan untuk mendapatkan suatu bentuk data atau informasi yang tersimpan dimedia penyimpanan. Algoritma pencarian adalah langkah-langkah untuk mencari data atau informasi yang tersimpan menggunakan kata kunci. Dalam algoritma pencarian kata kunci digunakan sebagai masukan yang akan dicari kemudian diproses dan menghasilkan kesimpulan ditemukan atau tidak ditemukan. Algoritma pencarian dapat berupa pencarian sekuensial dan pencarian biner [4].

Binary search banyak diterapkan pada sistem aplikasi yang komplek, dimana dalam pencarian data yang besar pada sebuah data base yang besar pula sangat dibutuhkan metode pencarian data. Metode ini dibutuhkan karena data yang tersimpan pada data base sangat bervariasi seperti: data text, data multimedia maupun data numerik [5]

Binary search merupakan algoritma yang dikembangkan dengan ide dasar yang berbeda dalam penangan kasus pencarian data pada sebuah pemrograman [6].

Proses pencarian (search) data pada sebuah pemrograman merupakan tindakan untuk mencari data pada sebuah data base berdasarkan satu kunci (key) data [7].

\section{Algoritma Binary Search}

Metode Binary Search sangat efisien jika dibandingkan dengan metode pencarian Linier, dimana semua elemen di dalam array diuji satu per satu sampai ditemukan elemen yang diinginkan. Selain dari binary search, ada juga metode interpolaton search, (jump search, yang prinsip berkerjanya berdasarkan data terurut. Pada pencarian biner, data harus diurutkan. Proses pencariannya berawal dari membandingkan array menjadi dua. Jika data yang dicari lebih kecil dari data yang terletak di tengah-tengah, maka proses pencariannya akan berlanjut kesebelah kiri dengan cara membagi array sebelah kiri menjadi dua. Sebaliknya jika data yang dicari lebih besar dari data yang terletak ditengah, maka proses pencariannya akan berlanjut kesebelah kanan dengan kembali membagi array menjadi dua bagian dan mencari titik tengahnya. Proses pembagiannya akan berulang hingga ditemukan data yang dicari [8].

Binary Search akan bekerjadengan normal jika data yang akan dikelola telah diurukan. Binary Search sangat sering digunakan dalam kehidupan sehari-hari. Seperti: jika hendak mencari suatu kata dalam kamus [9].

Binary Search hanya diterapkan pada elemen yang telah diurutkan (sorted). Pencarian beruntun telah memiliki satu kekurangan, yaitu dalam kasus elemen yang pencariannya berbeda pada posisi terakhir, maka harus dilakukan pencarian sepanjang larik. Data yang telah diurutkan terlebih dahulu akan menunjukkan kinerja pencarian yang lebih baik [10].

\section{Java}

Java merupakan bahasa pemrograman komputer diberbagai plaform terasuk ponsel. Pembuat bahasa pemrograman java ini awalnya adalah James Gosling saat masih bergabung dengan sun Microsystems dan telah terilis tahun 1995. Gosing memilih bahasa pemrograman ini karena kesukaannya terhadap kopi yang biasa di minum. Menurut berbagai sumber, asal kopi itu dari pulau jawa [11].

\section{Data}

Pengertian data menurut ahli dapat di kemukakan sebagai berikut :

Apapun kenyataan yang mengandung pengetahuan telah dijadikan dasar untuk menyusun, membuat kesimpulan atau menetapkan keputusan menurut Liang Gie.

Suatu alur yang digunakan untuk keterangan menghitung dan mengelola serangkaian tindakan atau operasi disebut data menurut S.P Siagian [12].

\section{METODE PENELITIAN}

Pada penelitian ini menggunakan metode Algoritma pencarian Binary untuk pencarian data barang produksi, akan dilakukan beberapa tahap yang meliputi.

a. Perancangan sistem menggunakan unified Modeling Language (UML)

b. Pengumpulan data topi, data dasi, data kaos kaki, data bad, data ikat pinggang.

c. Metode menggunakan algoritma Binary Search.

d. Implementasi menggunakan java Programming. 
e. Pengujian Sistem terbagi menjadi 2 tahap yaitu pengujian terhadap waktu pencarian dan Uji Kelayakan sistem.

f. Hasil aplikasi Pencarian data barang produksi dengan metode algoritma Binary Search.

\section{IV.HASIL DAN PEMBAHASAN}

\section{Analisa Sistem}

Sistem yang berjalan, dalam pencarian data barang produksi Konveksi menggunakan cara manual yaitu mencari satu-persatu dari arsip tertulis sehingga membutuhkan waktu dalam pencarian.

Sistem baru Dalam pencarian data barang produksi Konveksi dengan aplikasi menggunakan algoritma binary searchsehingga lebih mempermudah, lebih tepat dan akurat dalam pencarian data barang.

\section{Perancangan sistem}

\section{A. User Case Diagram}

Aktor atau pengguna dari sistem adalah admin gudang dapat melakukan login, memilih menu, input data, cari data, edit data, hapus data, ganti password, keluar aplikasi.User Case Diagram aplikasi pencarian barangakan ditunjukkan pada Gambar 1.

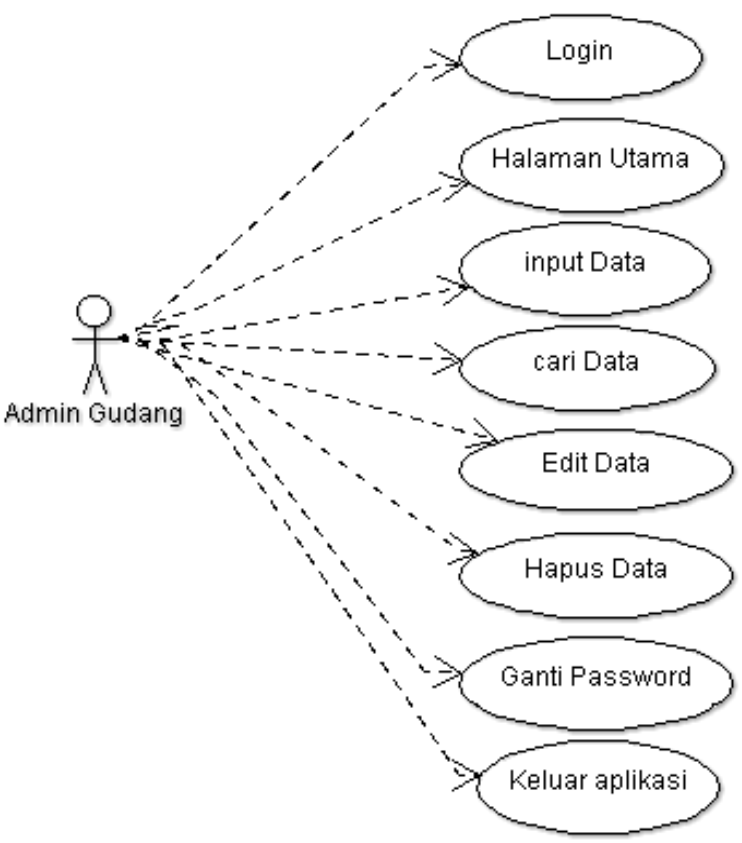

Gambar1.User Case Diagram

\section{User Case Cari Data}

Pada bagian User case ini actor dapat mencari data yang sedang di cari. Deskripsi User Case ditunjukkan pada Tabel 1.
Tabel 1. Deskripsi User Case Cari Data

\begin{tabular}{|l|l|}
\hline Nama User Case & Login \\
\hline Aktor & Admin Gudang \\
\hline Deskripsi & Mencari Data \\
\hline Kondisi Awal & $\begin{array}{l}\text { Sistem menampilkan } \\
\text { halaman utama }\end{array}$ \\
\hline Aktor & Sistem \\
\hline $\begin{array}{l}\text { 1. Aktor memilih } \\
\text { menu }\end{array}$ & $\begin{array}{l}\text { 2. Sistem menampilkan } \\
\text { sub menu }\end{array}$ \\
\hline $\begin{array}{l}\text { 3. Aktor memilih sub } \\
\text { menu }\end{array}$ & $\begin{array}{l}\text { 4. Sistem menampilkan } \\
\text { halaman form }\end{array}$ \\
\hline $\begin{array}{l}\text { 5. Aktor mencari } \\
\text { data }\end{array}$ & $\begin{array}{l}\text { 6. Sistem menampilkan } \\
\text { data yang di cari }\end{array}$ \\
\hline
\end{tabular}

B. Interaction sequence Diagram

Admin memilih sub menu sistem menampilkan hamalan form, admin mencari data sistem menampilkan data yang dicari admin, dapat dilihat pada Gambar 2.

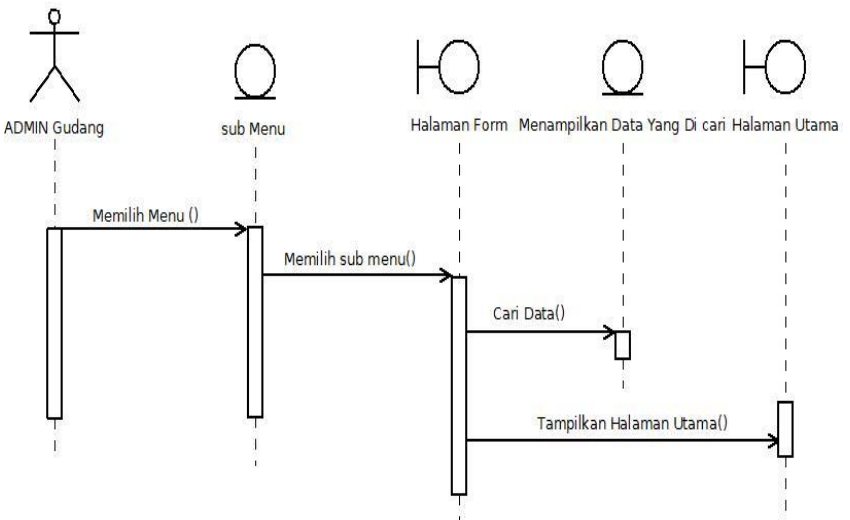

Gambar 2.Sequence Diagram mencari data

C. Activity Diagram

Activity Diagram pencarian data dilakukan admin. Aktivitas Admin dengan sistem dalam mencari data dapat dilihat pada Gambar 3.

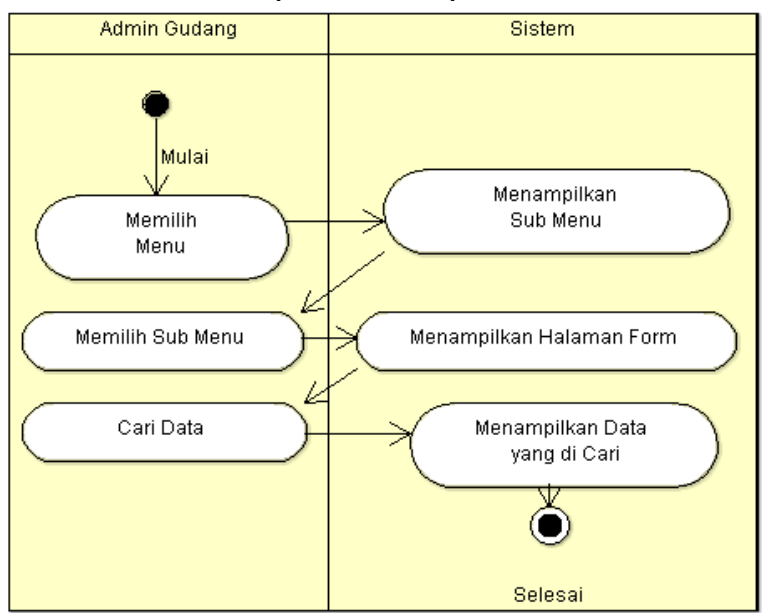

Gambar 3. Activity diagram mencari data

Deskripsi activity diagram cari data ditunjukkan pada Tabel 2. 
Tabel 2. Deskripsi Activity Diagram Cari Data

\begin{tabular}{|l|l|}
\hline \multicolumn{1}{|c|}{ Admin Gudang } & \multicolumn{1}{|c|}{ Sistem } \\
\hline 1. Klik menu & $\begin{array}{l}\text { 2. menampilkan sub } \\
\text { menu }\end{array}$ \\
\hline 3. Klik sub menu & $\begin{array}{l}\text { 4. menampilkan } \\
\text { halaman form }\end{array}$ \\
\hline 5. mencari data & $\begin{array}{l}\text { 6. menampilkan data } \\
\text { yang di cari }\end{array}$ \\
\hline
\end{tabular}

\section{Class Diagram}

Class Dagram pencarian data terdapat Class login, class halaman awal, class input data, class cari data, class edit data, class hapus data, class ganti password, class keluar, class diagram aplikasi dapat dilihat pada Gambar 4.

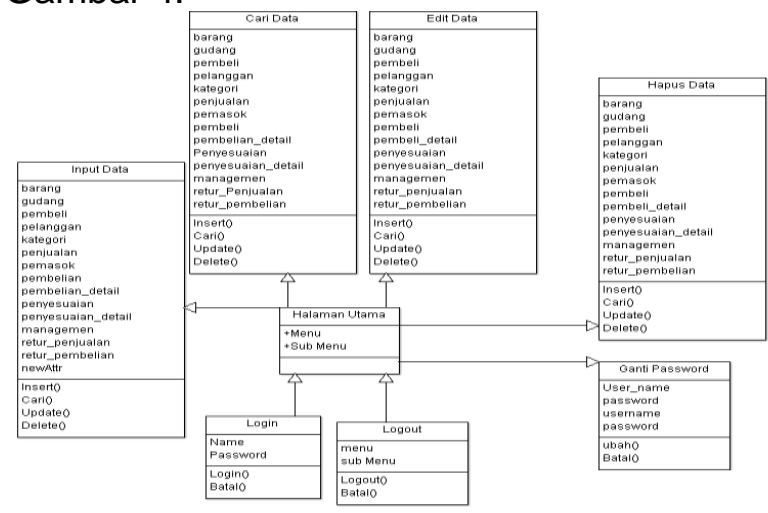

Gambar 4. Class diagram pencarian data

\section{Skema Relasi}

Relasi antara file merupakan gabungan antara file mempunyai kunci utama yang sama sehingga file-file tersebut menjadi satu kesatuan yang di kelompokkan menjadi satu fileld kunci tersebut. Elemen-elemen data yang di kelompokkan menjadi satu file data base beserta entitas dan hubunganya, dapat dilihat pada Gambar 5.

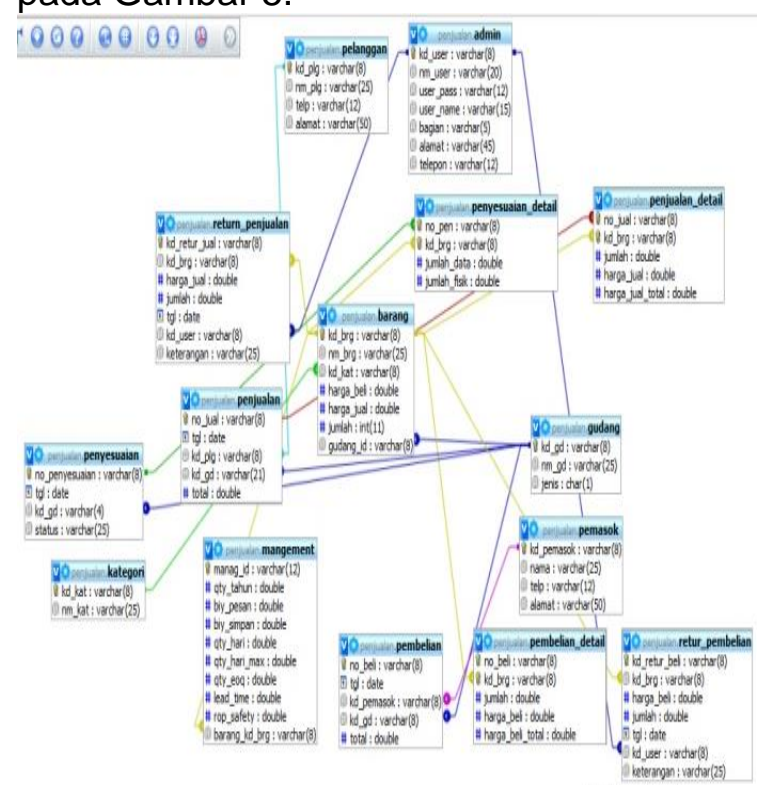

Gambar 5. Relasi pencarian barang

\section{E. Pencarian Dengan Binary Search}

Pada tahap ini akan mengelola data barang kedalam Binary Search. langkah awal yang akan dilakukan pada tahap ini adalah mengumpulkan data barang. Dalam peneltian ini penulis hanya menampilkan data testing yang akan digunakan untuk melakukan pencarian.

Setelah penulis menentukan data barang. Maka selanjutnya penulis akan mencari menggunakan Binary Search dengan mengacu pada langkah pencarian.

Data barang produksi yang akan dicari terlihat pada Tabel 3. Misalnya akan dicari data barang produksi "00003" maka akan dilakukan pencarian.

Tabel 3. Data barang produksi

\begin{tabular}{|l|l|l|l|l|l|}
\hline Kode & Nama & Kategori & $\begin{array}{l}\text { Harga } \\
\text { Beli }\end{array}$ & $\begin{array}{l}\text { Harga } \\
\text { Jual }\end{array}$ & Jumlah \\
\hline BRG00001 & $\begin{array}{l}\text { Muhamma } \\
\text { diyah }\end{array}$ & Topi SMP & 0.0 & 7000.0 & 75 \\
\hline BRG00002 & $\begin{array}{l}\text { Santa } \\
\text { Monica }\end{array}$ & Topi SD & 0.0 & 7500.0 & 100 \\
\hline BRG00003 & 5 Sandai & Topi SMP & 0.0 & 7500.0 & 50 \\
\hline BRG00004 & 1 Ketapang & Topi SMP & 0.0 & 7500.0 & 400 \\
\hline BRG00005 & 2 Ketapang & Topi SMP & 0.0 & 7500.0 & 270 \\
\hline BRG00006 & 4 Ketapang & Topi SMP & 0.0 & 7500.0 & 130 \\
\hline BRG00007 & 5 Ketapang & Topi SMP & 0.0 & 7500.0 & 200 \\
\hline BRG00008 & 6 Ketapang & Topi SMP & 0.0 & 7500.0 & 300 \\
\hline BRG00009 & 7 Ketapang & Topi SMP & 0.0 & 7500.0 & 100 \\
\hline BRG00010 & 8 Ketapang & Topi SMP & 0.0 & 7500.0 & 54 \\
\hline
\end{tabular}

Pada Tabel 4 diperlihatkan sebuah larik dengan sepuluh buah elemen yang sudah terurut dengan type data array yang akan dicari adalah "0003".

Tabel 4. Larik sepuluh elemen

\begin{tabular}{|l|l|l|l|l|l|l|l|l|l|l|}
\hline Nilai & 00001 & 00002 & 00003 & 00004 & 00005 & 00006 & 00007 & 00008 & 00009 & 00010 \\
\hline Indeks & 1 & 2 & 3 & 4 & 5 & 6 & 7 & 8 & 9 & 10 \\
\hline
\end{tabular}

\section{F. Hasil Pencarian}

Hasil pencarian hasil dari mencari data sebagi contoh mencari data dengan memasukkan kode data BRG00003 maka tabel di bawah akan menampilkan data, dapat dilihat pada Gambar 6. 


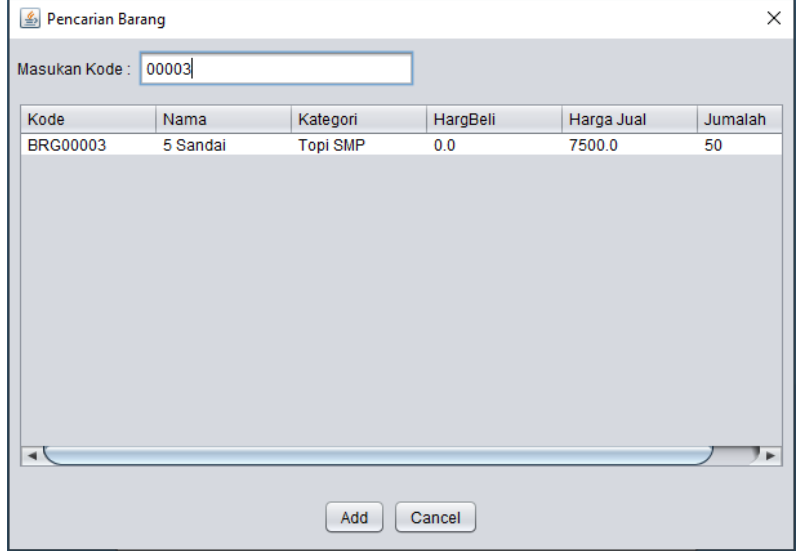

Gambar 6. Hasil Pencarian

\section{G. Pengujian Sistem}

Pengujian sistem yang dilakukan meliputi pengujian terhadap waktu pencarian. Uji coba dilakukan data testing 10 data dengan masingmasing kata atau karakter.

Tabel 5. Pengujian sistem

\begin{tabular}{|l|l|l|l|l|}
\hline No & $\begin{array}{l}\text { Jumlah } \\
\text { karakter }\end{array}$ & $\begin{array}{l}\text { Jumlah } \\
\text { karakter } \\
\text { yang } \\
\text { Benar }\end{array}$ & $\begin{array}{l}\text { Perse } \\
\text { ntase } \\
(\%)\end{array}$ & $\begin{array}{l}\text { Durasi } \\
\text { Waktu }\end{array}$ \\
\hline BRG00001 & 8 & 8 & 100 & 0.0005 \\
\hline BRG00002 & 8 & 8 & 100 & 0.0005 \\
\hline BRG00003 & 8 & 8 & 100 & 0.0005 \\
\hline BRG00004 & 8 & 8 & 100 & 0.0004 \\
\hline BRG00005 & 8 & 8 & 100 & 0.0005 \\
\hline BRG00006 & 8 & 8 & 100 & 0.0006 \\
\hline BRG00007 & 8 & 8 & 100 & 0.0004 \\
\hline BRG00008 & 8 & 8 & 100 & 0.0004 \\
\hline BRG00009 & 8 & 8 & 100 & 0.0004 \\
\hline BRG00010 & 8 & 8 & 100 & 0.0004 \\
\hline Rata -Rata Presentase kebenaran & 100 & \\
\hline Rata -Rata Durasi Waktu \\
\hline
\end{tabular}

Pengujian waktu pencarian menggunakan Mysql dengan cara membukak database penjualan di dalam penjualan terdapat tabel barang karena kita yang di cari data barang maka yang di bukak tabel barang maka data barang akan di tampilkan, dibagian atas data barang terdapat page number yang di gunakan untuk mencari data, sebagai contoh kita mencari data BRG00003 maka kita pilih page number 3 data akan di tampilkan, dibagian atas page number terdapat waktu pencarian 3 dari 210 data. Membutuhkan waktu $0.00005 \mathrm{sec}$, dapat dilihat pada Gambar 7.

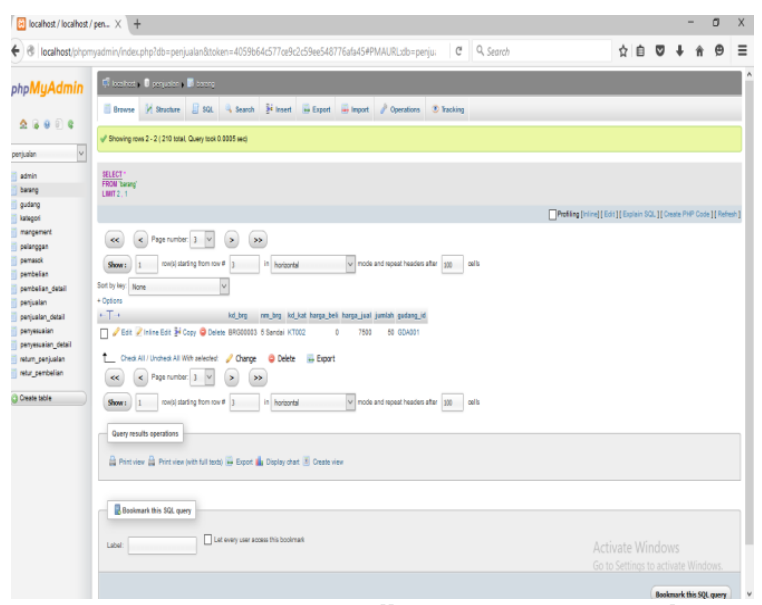

Gambar 7. Pengujian waktu pencarian

\section{H. Uji kelayakan}

Pengujian kelayakan adalah pengujian sistem oleh pengguna sistem, dengan menggunkan kuisioner yang disebarkan sebanyak 10 kuesioner kepada pegawai.

Tabel 6. hasil kelayakan uji

\begin{tabular}{|c|c|c|c|c|c|c|c|c|c|c|c|c|}
\hline No & Pertanyaan & $\begin{array}{l}R \\
1 \\
\end{array}$ & $\begin{array}{l}R \\
2 \\
\end{array}$ & $\begin{array}{l}R \\
3 \\
\end{array}$ & $\begin{array}{l}R \\
4 \\
\end{array}$ & $\begin{array}{c}R \\
5 \\
\end{array}$ & $\begin{array}{l}R \\
6 \\
\end{array}$ & $\begin{array}{l}\mathrm{R} \\
7 \\
\end{array}$ & $\begin{array}{l}R \\
8\end{array}$ & $R$ & 10 & Rate \\
\hline 1 & $\begin{array}{l}\text { Bagaimana pendapat anda mengenai } \\
\text { tampilan desain dan wama aplikasi ? }\end{array}$ & 4 & 5 & 3 & 5 & 3 & 5 & 3 & 4 & 4 & 5 & 4,1 \\
\hline 2 & Apakah aplikasi imi mudah di gunakan? & 4 & 5 & 5 & 4 & 5 & 4 & 4 & 5 & 5 & 3 & 4,4 \\
\hline 3 & $\begin{array}{l}\text { Bagaimana kelengkapan informasi yang } \\
\text { tersedia dalam aplikasi ini? }\end{array}$ & 3 & 4 & 3 & 4 & 5 & 5 & 5 & 4 & 5 & 3 & 4,1 \\
\hline 4 & $\begin{array}{l}\text { Sejauh mana aplikasi ini membantu } \\
\text { dalam pencarian data barang? }\end{array}$ & 4 & 5 & 4 & 5 & 3 & 5 & 5 & 4 & 4 & 3 & $\overline{4,2}$ \\
\hline 5 & $\begin{array}{l}\text { Apakah informasi yang tersedia dalam } \\
\text { sistem ini sudah akurat? }\end{array}$ & 5 & 4 & 3 & 4 & 4 & 4 & 5 & 5 & 4 & 5 & 4,3 \\
\hline 6 & $\begin{array}{l}\text { Bagaimana pendapat anda mengenai } \\
\text { keseluruha pada aplikasi ini? }\end{array}$ & 3 & 5 & 4 & 5 & 3 & 5 & 3 & 4 & 5 & 4 & $\overline{4,1}$ \\
\hline & & & & & & & & & & & & 25,5 \\
\hline
\end{tabular}

Hasil pengujian kelayakan :

1. Dilakukan pengujian kelayakan terhadap 10 responden yang terdiri dari pegawai RND Mandiri mendapatkan rata-rata 25,5

2. Nilai rata-rata 25,5 dari nilai maksimal 30 maka dapat diambil kesimpulan bahwa kelayakan dari sistem adalah kearah baik.

\section{PENUTUP}

\subsection{Kesimpulan}

Berdasarkan hasil pembuatan aplikasi dapat dambil kesimpulan sebagai berikut :

1. Aplikasi ini dapat mencari data barang produksi atribut sekolah berdasarkan kode barang.

2. Dalam Aplikasi terdapat fasilitas Login, dan menu ubah password, form pengguna, form gudang, form kategori, form pemasok, form pelanggan, form penjualan, Form pembelian, return penjualan, input barang, Lihat isi gudang. 
3. Pengujian terhadap waktu pencarian dari 210 data masing-masing durasi waktu, 0.0004 detik, 0.0005 detik, 0.0006 detik, 0.0007 detik, 0.0008 detik, 0.0009 detik, 0.0010 detik, 0.0012 detik, 0.0014 detik, 0.0017 detik.

\subsection{Saran}

Seiring berkembangnya teknologi dari masa kemasa pengembangan sistem ini dapat dikembangkan menggunakan berbasis android dan dapat juga menggunakan bahasa pemrograman php.

\section{DAFTAR PUSTAKA}

[1] Budi Yatno, Penerapan File Dengan Metode Algoritma Binary Search dan Dengan Pendekatan Wildcard Character, Universitas pasir pengairan, 2017

[2] Rinaldi Muni, Leony Lidya, Algoritma dan Pemrogram Dalam Bahasa Pascal, c, Dan C++, Bandung: Informatika, 2016

[3] Ahmat Josi, Implementasi Motode Using Binary Search And Parsing Tree Dalam Perancangan Aplikasi Penerjemah Bahasa Belanda-Indonesia-Inggris, STMIK Prabumulih, 2017

[4] Andri, Penerapan Algoritma Pencarian Binary Search dan QuckSort Pada Aplikasi Kamus Bahasa Palembang Berbasis Web, Universitas Bima Darma, Palembang, 2019

[5] Yoga Religia, Analisis Algoritma Sequential Search Dan Binary Search Pada Big Data, SST Pelita Bangsa, 2019

[6] Desryanti Djo Radja, Dkk, Aplikasi Pencarian Kata Dalam DataBase Kamus Bahasa Kutai Menggunakan Metode Binary Search, Universitas Mulawarman, 2017

[7] Frengki Santoso, Analisa Pencarian Data *.doc Pada Komputer Menerapkan Metode Sequensial With Sentinel, STMIK Budi Darma, Medan, 2019

[8] Viska Mutiawani, 2014, Hashtable Sebagai Alternatif dan Algoritma Pencarian Biner Pada Aplikasi E-Acesia, Universitas Syiah Kuala, Banda Aceh

[9] Guntur Syahputra, Implementasi Teknik Binary Search Pada kamus ndonesiaBatak Toba, STMIK Pelita Nusantara Medan, Sumatra utara, Malang: Polinema press, 2016

[10] Anindhia Anggraeni, Rancang Bangun Aplikasi Kamus Indonesia-Korea Menggunakan Algoritma Binary Search, STMIK STMIK STIKOM Surabaya, Surabaya, 2016
[11] Ramadhani, DasarAlgoritma dan Struktur Data Dengan Bahasa Java, Sleman: Andi Yogyakarta, 2015

[12] Anis Sriana, Sistem Inventory Pada Toko Union Motor Menggunakan Metode Algoritma Binary Search, Universitas Almuslim, Aceh, 2018 